\title{
Effects of Cyclooxygenase Inhibition on the Response to Group B Streptococcal Toxin in Sheep
}

\author{
JORGE ROJAS, ${ }^{\left(35,{ }^{37)}\right.}$ LARS E. LARSSON, MARTIN L. OGLETREE, KENNETH L. BRIGHAM, ${ }^{(36)}$ AND \\ MILDRED T. STAHLMAN \\ Department of Pediatrics and Medicine, Vanderbilt University School of Medicine, Nashville, Tennessee, USA
}

\begin{abstract}
Summary
The effects of cyclooxygenase inhibition on the reaction to a toxin isolated from group B $\beta$-hemolytic streptococci, type III, were studied in seven sheep instrumented for chronic measurement of pulmonary lymph flow, pulmonary artery and left atrial pressures. Each sheep was infused with toxin alone on one day and with indomethacin plus toxin on a different day in random order. The toxin alone caused a two-phased reaction. After the infusion of toxin, alone, in the initial phase, pulmonary artery pressure increased from $16.5 \pm 1.2 \mathrm{mmHg}$ to $47.1 \pm 4.8 \mathrm{mmHg}$ and the rectal temperature rose from $39.7 \pm 0.13^{\circ} \mathrm{C}$ to $40.9 \pm 0.16^{\circ} \mathrm{C}$. During the second phase, the granulocyte count decreased to less than $10 \%$ of baseline values and the lymph protein clearance increased from $4.8 \pm 1.2 \mathrm{ml} / \mathrm{h}$ to $10.02 \pm 1.4 \mathrm{ml} / \mathrm{h}$, suggesting increased pulmonary vascular permeability. Indomethacin pretreatment prevented the initial phase of pulmonary hypertension, the increases in thromboxane and prostacyclin metabolites in lung lymph, and the febrile response to toxin infusion but did not modify the granulocytopenia or the increased pulmonary vascular permeability. It appears that the hemodynamic changes are independent from the pulmonary vascular changes, and that prostaglandin endoperoxides or their metabolites are necessary for the fever and the acute pulmonary hypertension.
\end{abstract}

\section{Abbreviations}

GBS, group B streptococci

$\mathrm{PGH}_{2}$, prostaglandin $\mathrm{H}_{2}$

$\mathrm{TxB}_{2}$, thromboxane $\mathbf{B}_{2}$

We have previously reported that the infusion of a toxin isolated from Type III group B streptococci into sheep causes pulmonary hypertension, fever, granulocytopenia and increased lung vascular permeability $(18,27,28)$. These effects may be relevant to the pathophysiology of early onset group B streptococcal septicemia in newborn infants.

Prostaglandins $\mathrm{E}$ and $\mathrm{F}$, as well as thromboxane, are released in several animal species in response to the infusion of gram-negative endotoxin $(1,2,14,19)$. This requires the conversion of free arachidonic acid to prostaglandin endoperoxide by the enzyme cyclooxygenase. Inhibitors of the same enzyme, such as indomethacin, have been shown to modify the acute hemodynamic effects of gram-negative endotoxin $(11,16,25,26,23)$. Furthermore, the infusion of arachidonic acid or the endoperoxide, prostaglandin $\mathrm{H}_{2}$, has been also shown to cause pulmonary hypertension in sheep $(4,24)$.

Human granulocytes elaborate stable prostaglandins (34). Weissman et al. (33) demonstrated that human granulocytes exposed to serum-treated zymosan avidly phagocytized the particles and generated large amounts of thromboxane. Indomethacin blocked thromboxane generation but neither interfered with par- ticle to cell contact, nor with other responses of the cells to surface stimulation (i.e., lysosomal enzyme release, superoxide anion generation).

Prostaglandins have also been implicated in the generation of fever in several species (22). Increases in prostaglandin $E$ in cerebrospinal fluid have been found during pyrogen-induced fever (9) and most antipyretic drugs inhibit prostaglandin synthesis by preventing metabolism of arachidonic acid to endoperoxides (32).

In the sheep model, the response to group B streptococcal (GBS) toxin is similar to that seen after the infusion of $E$. coli endotoxin or pseudomonas bacteria (27). There is an initial period of pulmonary hypertension, followed by granulocytopenia, fever, and increased pulmonary capillary permeability. To determine the role of prostaglandin synthesis on each aspect of the response, the effects of pretreatment with the cyclooxygenase inhibitor, indomethacin, were investigated in seven unanesthetized sheep, instrumented for chronic measurements of vascular pressures and lung lymph flow.

\section{MATERIALS AND METHODS}

Seven yearling sheep $(35-45 \mathrm{~kg}$ ) were prepared for chronic lung-lymph collection as has been previously described (27). Through bilateral thoracotomies, catheters were placed directly into the main pulmonary artery, left atrium and the efferent duct from the caudal mediastinal lymph node. The tail of the node was resected to eliminate nonpulmonary lymph, and catheters placed in the right atrium and thoracic aorta through neck vessels. Lymph collected from animals prepared in this way has been shown to originate primarily from the lung because lymph flow increases when pulmonary vascular pressure is increased mechanically, but lymph flow does not increase when systemic venous pressure is increased.

All experiments were done with the sheep unanesthetized, standing unrestrained in a cage. Vascular pressures were measured continuously with pressure transducers (Statham P23Gb, GouldStatham Instruments, Inc., Hato Rey, Puerto Rico) and an electronic recorder (Hewlett-Packard Co., Palo Alto, CA). Lymph flow was measured at $15-\mathrm{min}$ intervals by recording the volume drained into a graduated tube. Total protein concentration was measured in plasma separated from blood drawn each hour, and in lymph pooled at 30-min intervals, using an automated system (AutoAnalyzer, Technicon Instrument Corp., Tarrytown, NY) by a modified Biuret method (4).

Lung-lymph protein clearance was calculated with the formula: $\mathrm{Cl}=\mathrm{LQ}(\mathrm{L} / \mathrm{P})$, where $\mathrm{LQ}$ is lymph flow and $\mathrm{L} / \mathrm{P}$ is the lymph/ plasma total protein concentration ratio.

Blood for white cell studies was drawn from the aortic catheter. Samples were obtained twice during the baseline period and then at $30,60,180$, and $300 \mathrm{~min}$ after the infusion of toxin. Total leukocyte counts were performed electronically in a model ZBI Coulter Counter (Coulter Electronics, Hialeah, FL), specifically 
adjusted for counting sheep leukocytes. Blood smears were stained with Wright's stain and subjected to a 200 cell differential count. Total granulocyte count was calculated by multiplying the total leucocyte count by the \% of granulocytes.

The isolation of the toxic polysaccharide has been described elsewhere (18). The dose used in all infusions was $2.0 \mathrm{mg}$ suspended in $80 \mathrm{ml}$ of $0.9 \% \mathrm{NaCl}$ solution. Experiments were done in pairs, each animal serving as its own control. Each sheep received toxin on one day and the same dose of toxin after pretreatment with indomethacin on a different day. The sequence of studies was varied to avoid bias and a minimum of 5 days was allowed between infusions.

All statistical calculations were done using a two-tailed paired $t$ test. A $P$ value of less 0.05 was considered significant.

\section{SPECIFIC PROTOCOLS}

Toxin alone. After a stable baseline period of at least $90 \mathrm{~min}, 2$ $\mathrm{mg}$ of toxin were infused intravenously over $15 \mathrm{~min}$ and hemodynamic and lymph flow data recorded for at least $5 \mathrm{~h}$ after the infusion.

Indomethacin and toxin. After a stable baseline period, a loading dose of $5 \mathrm{mg} / \mathrm{kg}$ of indomethacin was infused over $30 \mathrm{~min}$ followed by a maintenance dose of $3 \mathrm{mg} / \mathrm{kg} / \mathrm{h}$ for $3 \mathrm{~h}$. Indomethacin (Sigma Chemical Company, St. Louis, MO) was mixed immediately before each experiment with sodium carbonate powder (Matheson Company, Inc., Norwood, $\mathrm{OH}$ ) in a ratio of 3.1:1 in normal saline. The total volumes for the loading and maintenance dose were 60 and $180 \mathrm{ml}$, respectively. After infusing the indomethacin loading dose, $2 \mathrm{mg}$ of toxin were infused intravenously and the animal monitored for at least $5 \mathrm{~h}$. This dose of indomethacin produces blood plasma levels of approximately 0.5 $\mathrm{mcg} / \mathrm{ml}$, which is sufficient to inhibit prostaglandin synthesis (13). Ogletree and Brigham (23), have shown that with this dose indomethacin causes only transient elevations of pulmonary vascular pressures and lymph flow, without altering lung vascular permeability.

\section{ANALYSIS OF THROMBOXANE A2 AND PROSTACYCLIN METABOLITES}

Thromboxane $\mathrm{B}_{2}\left(\mathrm{TxB}_{2}\right)$ and 6-keto- $\mathrm{PGF}_{1 \alpha}$, stable hydrolysis products of thromboxane $\mathrm{A}_{2}$ and prostacycline respectively, were measured in lung lymph. Specimens were collected during the baseline period, $30 \mathrm{~min}$ after the peak in pulmonary artery pressure and $1 \mathrm{~h}$ into the steady-state second phase. Analyses were performed by radioimmunoassay, employing rabbit anti- $\mathrm{TxB}_{2}$ and anti-6-keto-PGF ${ }_{1 \alpha}$ antibodies obtained from Dr. J. Bryan Smith (Cardeza Foundation, Philadelphia, PA). The anti- $\mathrm{TxB}_{2}$ antibody cross reacts $<1 \%$ with $\mathrm{PGE}_{2}, \mathrm{PGF}_{2 \alpha}$ and 6 -keto- $\mathrm{PGF}_{1 \alpha}$ and $<3 \%$ with $\mathrm{PGD}_{2}$. The 6-keto-PGF $\mathrm{P}_{1 \alpha}$ antibody cross reacts $<3 \%$ with $\mathrm{PGF}_{2 \alpha}$ and $<1 \%$ with $\mathrm{PGE}_{2}, \mathrm{PGD}_{2}$, and $\mathrm{TxB}_{2}$. Authentic prostaglandins and $\mathrm{TxB}_{2}$ were generously supplied by Dr. John Pike (Upjohn Company, Kalamazoo, MI). Radiolabeled [5,6,8,9,11, $\left.12,14,15-{ }^{3} \mathrm{H}\right]-\mathrm{TxB}_{2}$ and $\left[5,6,8,9,11,12,14,15-{ }^{3} \mathrm{H}\right]-6-$ keto- $^{-} \mathrm{PGF}_{1 \alpha}$ were purchased from New England Nuclear (Boston, MA).

The radiolabeled ligand $(\simeq 2000 \mathrm{cpm}$ per tube) was first mixed with bovine $\gamma$-globulins ( $10 \mathrm{mg} / \mathrm{ml}$ in Trizma, pH 7.4). To $100 \mu \mathrm{l}$ aliquots of this mixture were added $100 \mu \mathrm{l}$ aliquots of sample or unlabeled standard dilutions. The binding reaction was initiated by addition of $100 \mu 1$ of antibody diluted to produce $60 \%$ binding of radioactivity in the absence of unlabeled ligand. The binding reaction continued for $60 \mathrm{~min}$ at $37^{\circ} \mathrm{C}$ and was terminated by precipitation of the immune complexes with ammonium sulfate at a final concentration of $50 \%$ of saturation. After centrifugation at $2500 \times g$ at $4^{\circ} \mathrm{C}$ for $10 \mathrm{~min}, 300 \mu \mathrm{l}$ of supernatant was counted in Aquasol (New England Nuclear, Boston, MA). Each sample was assayed in duplicate. Duplicate determinations differed by $<10 \%$. The detection limit of both assays was $<20 \mathrm{pg}$.

\section{RESULTS}

Toxin alone. The response was biphasic as previously described (27). There was an initial phase of pulmonary hypertension and high flow of protein-poor lymph, followed by a second phase when pulmonary artery pressure was slightly above baseline and stable, lymph flow was twice the baseline value, and the ratio of protein concentration in lymph to that in plasma increased. The data is summarized in Table 1.

During the second phase, lung lymph flow was 2 times higher than baseline and the lymph to plasma protein concentration ratio had returned to near baseline, resulting in a significant increase in lymph protein clearance.

Rectal temperature increased from $39.68 \pm 0.13^{\circ} \mathrm{C}$ during the baseline period to $40.88 \pm 0.16^{\circ} \mathrm{C}$ after the infusion of toxin ( $\mathrm{P}$ $<0.05)$.

The baseline white blood cell values for all sheep were within the normal range for sheep, as described by Schalm (30). The total white blood cell count dropped within the first hour after the infusion of the polysaccharide to $30 \%$ of baseline values. This leukopenia was due, primarily, to a decrease in granulocytes. The absolute granulocyte count fell to $10 \%$ of baseline values by 60 $\mathrm{min}$, followed by a slow recovery over the next $4 \mathrm{~h}$ (Fig. 1).

Indomethacin and toxin. Figure 2 shows the time course for the mean values of pulmonary vascular pressures for the seven pairs of experiments. The indomethacin loading dose caused a small and transient increase in left atrial pressure. After the infusion of toxin, the initial pulmonary hypertension was abolished but the delayed increase in pulmonary artery pressure was not prevented. When indomethacin was stopped there was a further increase in pulmonary artery pressure.

Lymph flow was unchanged during the first phase, but doubled during the second phase, with a concomitant increase in lymph to plasma protein concentration ratio, resulting in a significant increase in protein clearance comparable to that of the experiments where toxin was infused alone (Table 1).

The increase in rectal temperature was also prevented by in-

Table 1. Hemodynamic and lymph data for experiments with toxin alone and pretreatment with indomethacin

\begin{tabular}{|c|c|c|c|c|c|}
\hline & \multicolumn{2}{|c|}{ Mean pressure $(\mathrm{mm} \mathrm{Hg})$} & $\begin{array}{c}\text { Lymph flow } \\
(\mathrm{ml} / \mathrm{h})\end{array}$ & Lymph/plasma ratio & $\begin{array}{l}\text { Protein clearance } \\
(\mathrm{ml})\end{array}$ \\
\hline \multicolumn{6}{|l|}{ Toxin alone $N=7$} \\
\hline Phase I & $47.1 \pm 4.8^{2,3}$ & $3.1 \pm 1.7$ & $20.1 \pm 2.6^{2,3}$ & $0.59 \pm 0.02^{2,3}$ & \\
\hline Phase II & $21.9 \pm 1.9^{2}$ & $4.7 \pm 1.0$ & $14.1 \pm 1.7^{2}$ & $0.71 \pm 0.02$ & $10.02 \pm 1.4^{2}$ \\
\hline \multicolumn{6}{|c|}{ Indomethacin and toxin $N=7$} \\
\hline Phase II & $23.2 \pm 1.4^{2}$ & $4.9 \pm 0.9$ & $14.3 \pm 1.6^{2}$ & $0.71 \pm 0.02$ & $10.12 \pm 1.6^{2}$ \\
\hline
\end{tabular}

\footnotetext{
${ }^{1}$ All values mean \pm S.E.

${ }^{2} P<0.05$ compared to "Baseline."

${ }^{3} P<0.05$ compared to "Indomethacin."
} 




Fig. 1. A bsolute granulocyte counts for seven sheep during the reaction to group B streptococcal toxin alone ( - ) and during the reaction to group B streptococcal toxin after pretreatment with indomethacin $(---)$. There were no significant differences. Bars represent mean \pm S.D.

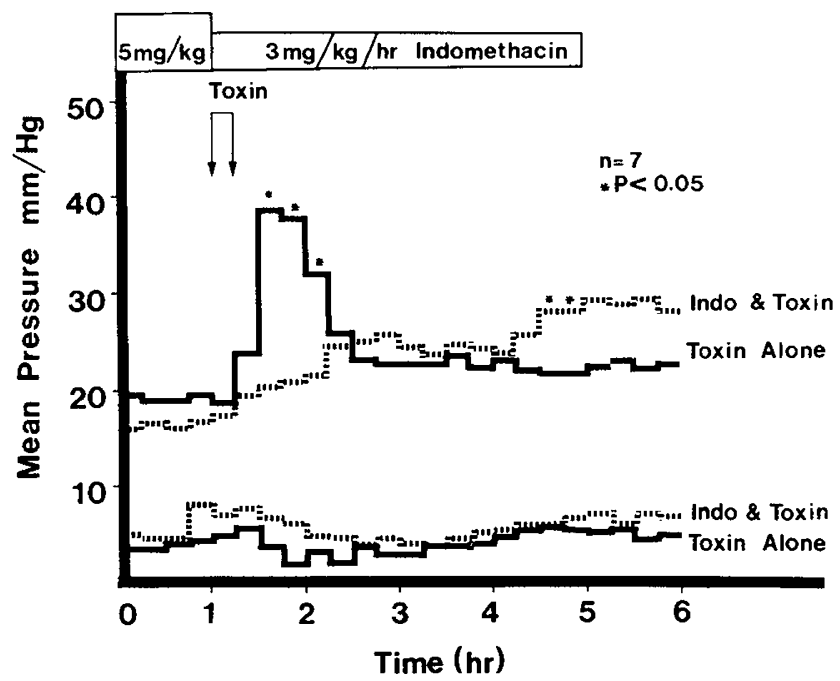

Fig. 2. Average responses of pulmonary artery and left atrial pressures for seven sheep during the infusion of group B streptococcal toxin alone $(-)$ and during the infusion of group B streptococcal toxin after pretreatment with indomethacin $(---)$.

domethacin. There was actually a small decrease from $39.15 \pm$ $0.15^{\circ} \mathrm{C}$ during the baseline period to $38.5 \pm 0.14^{\circ} \mathrm{C}$ postinfusion. This was significantly different $(P<0.05)$ from the toxin experiments.

The total white blood cell count and the granulocyte count were not significantly different at any time from the experiments with toxin alone (Fig. 1). There was a precipitous decrease in the first hour, followed by a slow recovery over $4 \mathrm{~h}$.

Thromboxane $A_{2}$ and prostacyclin metabolites. Table 2 shows the results of the measurements of thromboxane $\mathrm{B}_{2}$ and 6-keto$\mathrm{PGF}_{\mathrm{I} \alpha}$ concentration in lung lymph for seven experiments with toxin and three of the experiments where there was pretreatment with indomethacin. Thromboxane $\mathrm{B}_{2}$ concentration in lung lymph increased during the initial pulmonary hypertension and remained elevated during the second phase. There was also a small increase on 6-keto-PGF ${ }_{1 \alpha}$ during the initial phase which returned to baseline during Phase II. Indomethacin completely abolished the
Table 2. $T x B_{2}$ and 6-keto-PGF $F_{1 \alpha}$, stable metabolites of thromboxane $A_{2}$ and prostacyclin, in lung lymph for experiments done with toxin alone and pretreatment with indomethacin

\begin{tabular}{ccc}
\hline & $\begin{array}{c}\mathrm{TxB}_{2} \\
(\mathrm{ng} / \mathrm{ml})\end{array}$ & $\begin{array}{c}\text { 6-Keto-PGF } \\
(\mathrm{ng} / \mathrm{ml})\end{array}$ \\
\hline Toxin alone $N=7$ & & \\
Baseline & $0.151 \pm 0.05^{1}$ & $0.148 \pm 0.08$ \\
Phase I & $1.969 \pm 0.69^{2,3}$ & $0.823 \pm 0.33^{2,3}$ \\
$\quad$ Phase II & $0.721 \pm 0.49$ & $0.224 \pm 0.05$ \\
Indomethacin and toxin $N=3$ & \\
Baseline & $0.195 \pm 0.06$ & $0.323 \pm 0.27$ \\
Phase I & $<0.02$ & $0.023 \pm 0.001$ \\
Phase II & $<0.02$ & $0.064 \pm 0.05$ \\
\hline
\end{tabular}

'All values mean \pm S.E.

${ }^{2} P<0.05$ compared to "Baseline."

${ }^{3} P<0.05$ compared to "Indomethacin."

increase in lymph thromboxane $\mathrm{B}_{2}$ and 6-keto-PGF ${ }_{1 \alpha}$ concentrations after the toxin.

\section{DISCUSSION}

Pulmonary hypertension and granulocytopenia are an integral part of early onset GBS disease in newborn infants (3). The infusion of a toxin isolated from the same organism into unanesthetized sheep reproduces these findings, providing a model in which to study the pathophysiologic mechanisms of the disease. In this study, indomethacin inhibited the transient pulmonary hypertensive phase and the febrile response, but did not prevent the granulocytopenia, nor the increased lung vascular permeability. These results are consistent with those seen with the infusion of gram-negative endotoxin after cyclooxygenase inhibition (23) and are suggestive of a common pathway.

Infusing the cyclooxygenase product, prostaglandin $\mathrm{H}_{2}\left(\mathrm{PGH}_{2}\right)$, produces pulmonary vasoconstriction in unanesthetized sheep (4). The production of prostaglandins or thromboxanes requires $\mathrm{PGH}_{2}$ synthesis. Because inhibition of cyclooxygenase inhibits $\mathrm{PGH}_{2}$ synthesis and prevents the pulmonary hypertensive phase, it is likely that $\mathrm{PGH}_{2}$ or one of its metabolites is responsible for the increase in pulmonary vascular pressure. The elevation in the concentration of thromboxane $\mathrm{A}_{2}$ and prostacyclin metabolites in lung lymph, during the initial phase is consistent with an increase synthesis of cyclooxygenase products. Thromboxane $\mathrm{A}_{2}$, a potent vasoconstrictor, may be responsible for the pulmonary hypertension seen during this phase.

Inhibition of the febrile response supports the hypothesis that central action of prostaglandins may be a factor in the genesis of fever $(9,22)$. The decrease in rectal temperature in those animals given indomethacin is similar to that observed in guinea-pigs, and may reflect a direct effect of the drug on the thermoregulatory center (31).

Even though indomethacin prevented the initial pulmonary hypertension after GBS toxin, it did not modify the granulocytopenia nor the increased pulmonary vascular permeability. The mechanism involved in the pathogenesis of these changes, therefore, seems to be independent from prostaglandin synthesis.

Pulmonary leukostasis and leukopenia are known to occur during adult respiratory distress syndrome (20), hemodyalisis (8), and cardiopulmonary bypass (5). Complement activation is assumed to be the cause because similar changes develop in several animal species shortly after the infusion of autologous plasma which has been exposed to complement activating agents, including polysaccarides such as inulin, zymosan or polycellulose membranes of hemodialysis coils (7). Complement activation through the alternative pathway, characteristic of gram-negative endotoxin shock (21), has also been shown to occur in infants with early onset group B streptococcal disease (10). It is tempting to postulate a similar mechanism, independent of prostaglandin synthesis, in the reaction to GBS toxin. 
Granulocyte depletion has been shown to prevent the pulmonary vascular changes due to gram-negative endotoxemia (17) or microembolization (12). Granulocytes are capable of the production of free oxygen radicals, lysosomal enzymes and arachidonate products which have been shown to injure vascular endothelium $(6,15,29)$. The changes in pulmonary vascular permeability may possibly be due to these products.

In summary, cyclooxygenase inhibition with indomethacin blocks the pulmonary hemodynamic changes and the febrile response that follow the infusion of GBS toxin into sheep. The conversion of arachidonate to prostaglandin endoperoxides seems necessary for these changes. The granulocytopenia and the increased pulmonary vascular permeability seem to be independent from prostaglandin synthesis, and further studies will be necessary to elucidate the mechanisms involved in their production.

\section{REFERENCES AND NOTES}

1. Anderson, F. L., Jubiz, W., Theophilus, T. J., and Kuida, H.: Endotoxin induced prostaglandin E and F release in dogs. Am. J. Physiol., 228: 410 (1975).

2. Anderson, F. L., Theophilus, T. J., Jubiz, W., and Kuida, H.: Prostaglandins F and $E$ levels during endotoxin induced pulmonary hypertension in calves. Am J. Physiol., 228: 1479 (1975).

3. Baker, C. J.: Group B streptococcal infection in neonates. Pediatrics in Review. 1: 5 (1979)

4. Bowers, R. E., Ellis, E. F., Brigham, K. L., and Oates, J. A.: Effects of prostaglandin cyclic endoperoxides on the lung circulation of unanesthetized sheep. J. Clin. Invest., 63: 131 (1979).

5. Chinoweth, D. E., Cooper, S. W., Hugli, T. E., Stewart, R. W., Blackstone, E. H., and Kirklin, J. W.: Complement activation during cardiopulmonary bypass. Evidence for generation of $\mathrm{C}_{3} \mathrm{a}$ and $\mathrm{C}_{5}$ a anaphylatoxins. N. Engl. J. Med., 304: 497 (1981)

6. Cochrane, C. G., and Aikin, B. S.: Polymorphonuclear leukocytes in immunologic reactions. The destruction of vascular basement membrane in vivo and in vitro. J. Exp. Med., 124: 733 (1966).

7. Craddock, P. R., Fehr, J., Brigham, K. L., Kronenberg, R. S., and Jacob, H. S. Complement and leukocyte-mediated pulmonary dysfunction in hemodyalisis. N. Engl. J. Med., 296: 769 (1977).

8. Craddock, P. R., Fehr, J., Dalmasso, A. P., Brigham, K. L., and Jacob, H. S.: Hemodyalisis leukopenia. Pulmonary vascular leukostasis resulting from complement activation by dialyzer cellophane membranes. J. Clin. Invest., 59: 879 (1977).

9. Feldberg, W., and Gupta, K. P.: Pyrogen fever and prostaglandin-like activity in cerebrospinal fluid. J. Physiol. (London), 228: 41 (1973)

10. Fenton, L. J., and Strunk, R. C.: Complement activation and group B streptococcal infection in the newborn: Similarities to endotoxin shock. Pediatrics, 60: 901 (1977).

11. Fletcher, J. R., and Ramwell, P. W.: E. Coli endotoxin shock in the dog; treatment with lidocaine or indomethacin. Br. J. Pharmacol., 64: 185 (I978).

12. Flick, M. R., Perel, A., and Staub, N. C.: Leukocytes are required for increased lung microvascular permeability after microembolization in sheep. Circ. Res. 48: 344 (1981).

13. Flower, R. J., and Vane, J. R.: Inhibition of prostaglandin biosynthesis. Biochem. Pharm. 23: 1439 (1974).

14. Frolich, J. C., Ogletree, M. L., and Brigham, K. L.: Pulmonary hypertension correlated to pulmonary thromboxane synthesis. Advances in Prostaglandin and Thromboxane Research, 7: 745 (1980).

15. Goetzel, E. J.: Mediators of immediate hypersensitivity derived from arachidonic acid. N. Engl. J. Med., 303: 822 (1980).

16. Hall, R. C., Hodge, R. L., Irvin, R., Katec, F., and Middleton, J. M.: The effect of aspirin on the response to endotoxin. Aust. J. Exp. Biol. Med. Sci., 50: 589 (1972)

17. Heflin, A. C., and Brigham, K. L.: Granulocyte depletion prevents increased lung vascular permeability after endotoxemia in sheep. Clin. Res., 27: 399A (1979).

18. Hellerqvist, C. G., Rojas, J., Green, R. S., Sell, S., Sundell, H., and Stahlman, M. T.: Studies on Group B $\beta$-hemolytic streptococcus: I. Isolation and partial characterization of an extracellular toxin. Pediatr. Res., 15: 892 (1981).

19. Hyman, A. L., Spaunhake, E. W., and Kadowitz, P. J.: Prostaglandins and the lung. Am. Rev. Resp. Dis., 117: 111 (1978)

20. Jacob, H. S., Craddock, P. R., Hammerschmidt, D. E., and Moldow, C. F Complement-induced granulocyte aggregation. An unsuspected mechanism of disease. N. Engl. J. Med., 302: 789 (1980)

21. McCabe, W. R.: Serum complement levels in bacteremia due to gram-negative organisms. N. Engl. J. Med., 288: 21 (1973).

22. Milton, A. S. and Wandland, S.: Effects on body temperature of prostaglandins of the $\mathrm{A}, \mathrm{E}$ and $\mathrm{F}$ series on injection into the third ventricle of unanesthetized cats and rabbits. J. Physiol (London), 218: 325 (1971).

23. Ogletree, M. L. and Brigham, K. L.: Effects of cyclooxygenase inhibitors on pulmonary vascular responses to endotoxin in unanesthetized sheep. Prostaglandins, Leukotrienes and Medicine. 8: 489 (1982)

24. Ogletree, M. L., and Brigham, K. L.: Arachidonate raises vascular resistance but not permeability in lungs of awake sheep. J. Appl. Physiol., 48: 581 (1980)

25. Parrat, J. R. and Sturgess, R. M.: The effect of indomethacin on the cardiovascular and metabolic responses to $E$. Coli endotoxin in the cat. Br. J. Pharm., 50: 177 (1974).

26. Parrat, J. R. and Sturgess, R. M.: The effects of the repeated administration of sodium meclofenamate, an inhibitor of prostaglandins synthetase, in feline endotoxin shock. Circ. Shock, 2: 301 (1975).

27. Rojas, J., Green, R. S., Hellerqvist, C. G., Olegard, R., Brigham, K. L., and Stahlman, M. T.: Studies on Group B $\beta$-hemolytic streptococcus: II. Effects on pulmonary hemodynamics and vascular permeability in unanesthetized sheep. Pediatr. Res., 15: 899 (1981)

28. Rojas, J., Larsson, L. E., Hellerqvist, C. G., Brigham, K. L., and Stahlman, M. T.: Granulocyte response to Type III, Group B streptococcal toxin. Clin. Res. 28: 874A (1980)

29. Sacks, T., Moldow, C. F., Craddock, P. R., Bowers, T. K., and Jacob, H. S. Oxygen radicals mediate endothelial cell damage by complement-stimulated granulocytes. An in vitro model of immune vascular damage. J. Clin. Invest., 61: 1161 (1978).

30. Schalm, O. W., Ed: Veterinary Hematology, II Edition, Lea and Febiger, Philadelphia p. 237 (1971).

31. Szekely, M.: Endotoxin fever in the newborn Guinea-pig and the modulating effects of indomethacin and chlorophenylalanine. J. Physiol., 281: 467 (1978).

32. Vane, J. R.: Inhibition of prostaglandin synthesis as a mechanism of action for aspirin-like drugs. Nature New Biol., 231: 232 (1971).

33. Weissmann, G.: The release of arachidonic acid-derived products by the cells of inflammation. In Current Concepts: Prostaglandins in acute Inflammation. p. 14 (The Upjohn Company, 1980)

34. Zurier, R. B., and Sayadoff, D. M.: Release of prostaglandins from human polymorphonuclear leukocytes. Inflammation, I: 93 (1975).

35. Fellow supported by the Tennessee Lung Association.

36. This work was done under Dr. Brigham's tenure as an Established Investigator of the American Heart Association

37. Requests for reprints should be addressed to: Dr. Jorge Rojas, Department of Pediatrics, Vanderbilt University School of Medicine, Nashville, Tennessee 37232.

38. This work was supported by a grant from the National Institutes of Health HL 22520

39. We are indebted to Carl G. Hellerquist, from the Department of Biochemistry at Vanderbilt University, for providing with the toxin for all the experiments. We thank Gerda Resch, Patricia Minton and Rao Gaddipati for their expert technical assistance and Diane Peevler for her secretarial assistance in the preparation of the manuscript.

40. Received for publication February 8,1982

41. Accepted for publication June 11, 1982. 